\title{
Open Unemployment in The Province of Bali
}

\author{
${ }^{1}$ SURYA DEWI RUSTARIYUNI, ${ }^{2}$ LUH PUTU ASWITARI, ${ }^{3}$ PUTU WIDI SURYAWAN \\ RATHA, ${ }^{4}$ GEK AYU NINA
}

\footnotetext{
${ }^{1}$ Fakultas Ekonomi dan Bisnis Universitas Udayana, PB Sudirman Street Denpasar,

${ }^{2}$ Fakultas Ekonomi dan Bisnis Universitas Udayana, PB Sudirman Street Denpasar email : ${ }^{1}$ surwidwirca@gmail.com, 2niluhputu aswitari@unud.ac.id
}

\begin{abstract}
The high level of open unemployment in the districts/cities of Bali Province is not in line with the high minimum wage applied and the lower level of labor force participation. This study aims to analyze both the short and long-term district minimum wages (UMK), gross regional domestic product (GRDP), labor force participation rates (LFPR) and education on open unemployment in all districts/cities of Bali Province for the period of 2006 to 2017 . This study uses error correction model (ECM) analysis techniques. The research findings showed that in the short term the UMK and TPAK had a negative and significant effect on open unemployment; in the long run UMK, GRDP, and TPAK had a positive effect on open unemployment; the education elasticity had the greatest effect on open unemployment compared to other variables. This fact demands the Provincial Government of Bali to be more proactive in improving vocational education so that open unemployment will decrease
\end{abstract}

Keywords: Open unemployment, District/city minimum wage, Labor force participation rate

\section{Introduction}

Bali Province is one of the most famous tourist destinations in the world. The charm of natural beauty and customs with its own characteristics make the Province of Bali admired by domestic and foreign tourists. The tourism sector is still the driving force of local economy, but behind the popularity of tourism, it cannot escape various problems; one of which is employment problem. There is still unemployment in the districts/cities of Bali Province. It is a serious problem to be considered and must be overcome by the government which also needs support from all levels of society. According to Adipuryanti and Sudibia (2015), employment problems are a phenomenon that still needs to be addressed in Bali Province and the labor market in Bali Province is expected to be more integrated in the future.

In Figure 1, the open unemployment rate in districts/cities of Bali has fluctuated. The highest open unemployment rate in 2015 occurred in Denpasar City, which reached 3.54 percent, and the lowest rate was in Badung Regency, which was equal to 0.34 percent.
The persistence of open unemployment indicates that there are still people who have not optimally utilized their ability to meet their needs, so that efforts need to be made by the government to reduce unemployment and increase the productivity of human resources in districts/cities of Bali Province.

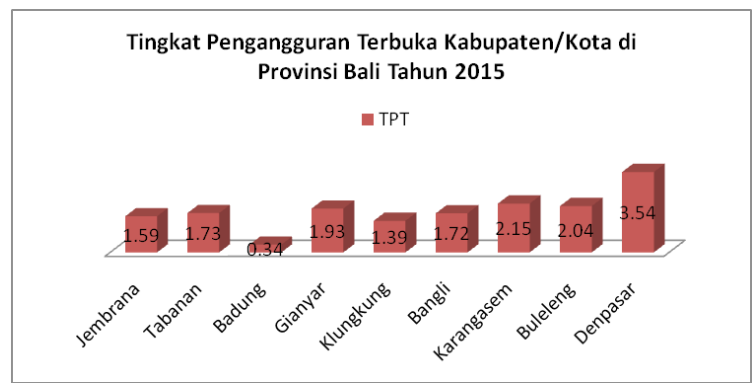

Figure 1. Open Unemployment Rate in Districts/Cities of Bali Province (in \%)

Source: Central Bureau of Statistics of Bali Province in various publications (processed)

Unemployment is a big problem that is always faced by developing countries. The high unemployment in a country results in

Received: July 07, 2018, Revision: September 13, 2018, Accepted: December 11, 2018

Print ISSN: 0215-8175; Online ISSN: 2303-2499. DOI: http://dx.doi.org/10.29313/mimbar.v34i2.3921.475-488

Accredited B based on the decree No.040/P/2014, valid on February, 18, 2014 until February, 18, 2019. Indexed by DOAJ, Sinta, IPI 
low community participation in economic growth which can have an impact on national economic development (Pratiwi and Zain, 2014). Unemployment can occur as a result of high rate of change in the workforce which is not balanced by the large number of jobs and the absorption of labor that tends to be smaller in percentage. This is due to the low growth rate of job creation to accommodate workers who are ready to work (Sisnita, 2017).

The economic growth of a country or region that continues to show an increasing trend indicates that the economy of a country or region is developing well. In order to realize high economic growth, local governments is expected to utilize all resources optimally (Fajrii and Yohanes, 2016). According to Suartha and Yasa (2017), economic growth will create a multiplier effect on various fields of life, such as the economic and socio-cultural environment of society. If economic growth is high, it will result in the lively economic activity and the broader employment opportunities.

In Figure 2, the largest amount of GRDP was obtained by Badung Regency, amounting to Rp. 29,178.33 (billion); and the second largest position was Denpasar City with a total GRDP of Rp. 28,433.25 (billion). The lowest GRDP was obtained by Bangli Regency, amounting to Rp. 3,688 (Billion). The results of research conducted by Latifah, et al (2017), Siregar (2017), Adawiyah and Seftarita (2016), Senet and Yuliarmi (2014), Oniore, et al (2015), Rahmadin, et al (2013), showed that economic growth has a negative influence on the unemployment rate.

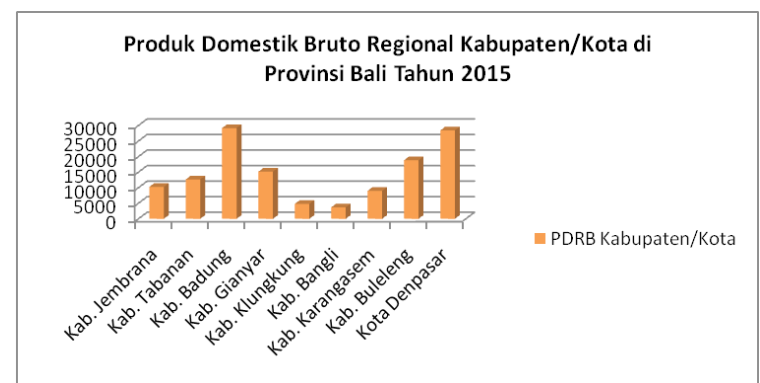

Figure 2. Districts / City GRDP in the Bali Province (in Billion Rupiah)

Source: Central Bureau of Statistics of Bali Province in various publications (processed)

The next major and fundamental problem of employment in Bali Province is the problem of low wages which directly and indirectly affecting the high unemployment rate. This is because the increases of prospective workforce are far greater than the growth of employment that can be provided annually. Wages are a quite interesting problem because most of the unemployed are picky in choosing jobs with high wages. Wages are a driving factor for unemployed people to get jobs immediately, because with a good wage level they can meet their needs.

According to Mankiw (2006), wages are one of the factors that influence the unemployment rate as well as compensation received by one unit of labor in the form of the amount of money paid. If in one country economic growth increases, it is expected to influence the decrease in number of unemployed, followed by the wage rate. If the wage level rises, it will affect the decrease of number of unemployed. The minimum wage level of Bali Province from 2006 to 2016 is shown in Figure 3. The annual increase of wages in Bali Province has not resulted in the decline of unemployment in all districts/ cities. The city of Denpasar experienced the highest Open Unemployment Rate in 2015 and Badung District had the lowest Open Unemployment Rate, which has not been followed by the increase in Provincial Minimum Wage.

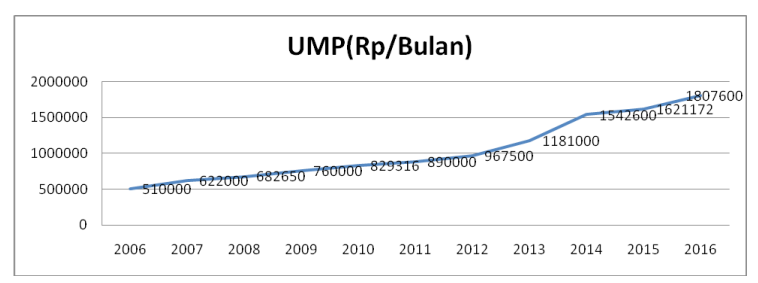

Figure 3. Bali Provincial Minimum Wages in 2006 to 2016 (Rupiah / Month)

Source: Central Bureau of Statistics various edits, processed data (2018)

The results of research conducted by Valentine (2018), Kurniawan (2017), Azwar (2016), and Putri (2015) show that minimum wages have a significant negative effect on the unemployment rate. Prawira (2018), Nurjanah (2017), Putro and Seriawan (2013), Hajji and Nugroho (2013) found that the results of the study were different from previous studies, namely, the wage rate had a positive and significant effect on the unemployment rate.

The results of Utami's study, et al (2016), Azwar (2016), Fatimah and Syahnur (2015) show that the level of labor force 
participation has a negative and significant effect on the unemployment rate. 1 percent increase in the male participation rate will reduce the unemployment rate by 0.12 percent and 1 percent increase in the female labor force participation rate will reduce the unemployment rate by 0.13 percent. The effect of male labor force participation is slightly smaller in reducing the unemployment rate compared to the female labor force because male unemployment is greater than female unemployment due to more male workforce.

Education is a pioneer in future development. Education is closely related to character building, and is one of the investments in human resources to get a better life. Someone who has higher education usually has greater access to higher paid employment compared to individuals with lower levels of education (Wiguna, 2013). Through better education, the poor will have a better opportunity to get out of his/her poor status in the future (Anderson, 2012). Education, in this case, is proxied by the average length of schooling.

Pratiwi and Zain (2014) state that the role of education affects unemployment, so it needs to increase its quality and quantity. Lathifah and Wibowo (2016) found that basic and higher education factors influence open unemployment in East Java. Unemployment problems are complex to discuss and are important issues because they can be linked to several indicators. The high and low unemployment rate is very important to measure the level of success in economic development. The higher education pursued by a person, the more abilities and skills he/ she will develop which later provides a greater opportunity to enter the labor market, so that it is expected to reduce unemployment. However, the reality shows that persons with high education are not necessarily employed in labor market. The large number of unemployed college graduates is due to the imbalance between the profiles of university graduates with the qualifications of ready-touse workers needed by companies.

Based on the results of a research study on talent management and rewards conducted by Willis Towers Watson since 2014, it was found that eight out of ten companies in Indonesia had difficulty in getting college graduates ready to work. Supposedly, the company has no difficulty in finding workforce because the growth rate of tertiary graduates in Indonesia increases every year, but the number of companies demand for labor is always lower than the number of college graduates (Kompas.com). This research was conducted to determine the effect of districts/cities minimum wages, economic growth (GRDP), labor force, and education participation rates on open unemployment rates in all districts/cities of Bali Province from 2006 to 2017 on a long and short-term basis.

\section{Research Methods}

Based on the high level of open unemployment in Bali Province which is not matched by the increase of provincial minimum wages, this research is carried out by analyzing the short-term and longterm variables of districts/cities minimum wages, economic growth (GRDP), labor force participation rates (LFPR) and education (RLS) on the open unemployment rate (TPT). The data analysis method used in this study was the time series data model obtained from multi years, i.e. from 2006 to 2017. The research data were obtained through Bali Provincial Statistics Bureau and the Regency/ City Statistics Bureau from 2006 to 2017 on Regency/City Minimum Wages, economic growth rates seen from the calculation of Gross Regional Domestic Product (GRDP) on the basis of constant prices, Labor Force Participation Rate (TPAK), education proxied by the average length of schooling, and the Open Unemployment Rate.

The data collection method used was documentation to obtain secondary data from relevant agencies, i.e. the Bali Provincial Central Bureau of Statistics (BPS) and the Regency/ City Statistic Bureaus. Data analysis techniques are carried out through various stages: Stationarity Test is a test conducted to determine whether a variable is stationary or not. The steps were to find the DF and $A D F$ value counted from the equations of all variables. If all variables is not stationary at the first degree, the stationary test would be carried out in the next stage with the degree of integration test because the DF and ADF values of all variables must have the same stationary degree. The equation of stationarity test variables is as follows:

$\Delta T P T_{1_{t}}=\alpha+\beta T P T_{1_{t-1}}+\delta_{1} \Delta T P T_{1} t-1+\delta_{2} \Delta T P T_{1_{t-1}}+\ldots \ldots .+\delta_{p} T P T_{1 t-p}+e$ ...(1)

$\mathrm{p}$ is the number of lags obtained, $\mathrm{N}$ is the amount of data. For time series data, 
Table 1

Stationary Test Phase II or I (1)

\begin{tabular}{llllll}
\hline & TPT/OUR & UMK/DMW & PDRB/GRDB & TPAK & RLS \\
\hline DF & $-2.8897 *$ & $-2.8897 *$ & $-2.8897 *$ & $-2.8897 *$ & $-2.8897 *$ \\
ADF & $-6.114731 *$ & $-6.362887 *$ & $-9.491809 *$ & $-6.354621 *$ & $-10.29949 *$ \\
\hline
\end{tabular}

Notes : $\left.{ }^{* *}\right)$ : significant at $a=1 \%$,

$*)$ : significant at $a=5 \%$

Source: research results, 2018

researchers need to test whether the data is stationary or non-stationary. If it is nonstationary, it will contain relatively high $\mathrm{R} 2$ and low Durbin Watson statistics (Insukindro, 1992). This condition will cause a problem known as Spurious Regression (Thomas, 1993: 15). The second stage was to carry out a cointegration test, which was done by regressing long-term equations, then keep the residuals. Cointegration tests can be done if all stationary variables are in the same degree, then the residuals from the long-term regression results are tested for stationarity; if the residuals are stationary, then the variables have a long-term balance. The third step was to carry out the classical assumption test. Estimated results of time data, in order to meet the criteria of the Best Linear Unbiased Estimate (BLUE), the classical assumption was tested which consists of the Normality test, Multicollinearity test, Autocorrelation test, and Heteroscedasticity test.

The final stage was the Error Correction Model test to get the results of short and longterm analysis. ECM is able to cover changes in open and long-term unemployment rates and to estimate the rate of change carefully in the long term compared to other dynamic models. The model used in this study was an econometric model with the following model specifications.

$\Delta T P T_{1}=\beta_{0}+\beta_{1} \Delta U M K_{r}+\beta_{2} \Delta P D R B+\beta_{3} \Delta T P A K+\beta_{4} \Delta R L S+\beta_{5} U M K_{t-1}$ $+\beta_{6} P D R B_{t-1}+\beta_{7} T P A K_{t-1}+\beta_{8} R L S_{t-1}+\beta_{9} E C T$

where:

$\Delta \mathrm{TPT}_{1}=$ change in open unemployment rate (percent) $\triangle \mathrm{UMK}=$ change in district/city minimum wage (Rupiah/month)

$\triangle P D R B=$ change in gross regional domestic product (percent)

$\triangle T P A K=$ changes in labor force participation rates (percent)

$\triangle$ RLS = change of average length of schooling (years)

$\mathrm{TPT}_{\mathrm{t}-1} \quad=$ the past open unemployment rate $\mathrm{UMK}_{\mathrm{t}-1}=$ the past district/city minimum wage PDRB $_{\mathrm{t}-1}=$ the past gross regional domestic product

TPAK $_{\mathrm{t}-1}^{\mathrm{t}-1}=$ the past labor force participation rate

$\mathrm{RLS}_{\mathrm{t}-1}^{\mathrm{t}-1}=$ the past average length of schooling

ECT = error coefficient term

\section{Integration Test}

The stationarity test results for all variables that were not stationary in the first stage, then stationarity tests were carried out in the second stage known as the integration tests. The following are the results of stationarity tests for all variables in the second stage (Table 1).

Table 1 shows that all variables were stationary, both DF and ADF were significant at $a=1 \%$ (if significant at $a=1 \%$, it also means significant at $a=5 \%)$. This means that all stationary variables were in the same degree, namely at degree 1 and all the variables above had co-integration candidates so that the next step of the test was continued to the cointegration test stage.

Table 2

\section{Cointegration Test Results}

\begin{tabular}{lll}
\hline Variable & ADF value & DF Value \\
Res_RKR $_{(-1)}$ & $-3.642666^{*}$ & -2.8895 \\
\hline
\end{tabular}

Source: research results, 2018

Based on table 2, it can be seen if stationary residuals are at the level, this indicates if there is a balance between variables in the same time period and all variables have a long-term balance, then the test continues to the next stage which is testing classical assumptions.

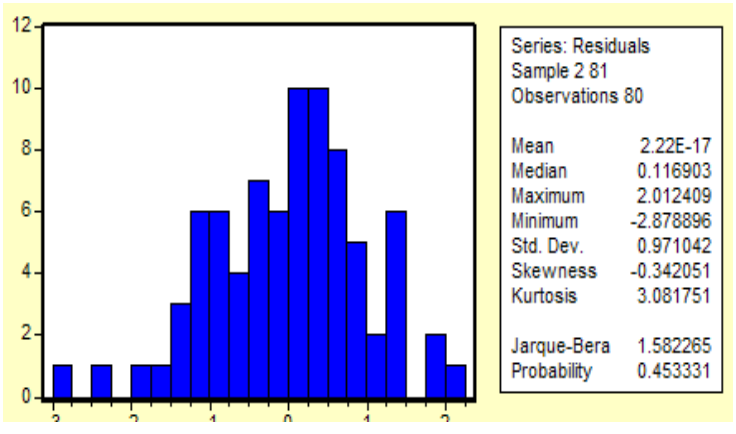

Source: research results, 2018

Figure 4. Normality Test Normality Test 
Figure 4 shows the results if the probability value of Jarque-Bera is 0.453 greater than 0.05 , meaning that the data used is normally distributed and allowed the next test to be carried out, namely Multicollinearity test.

\section{Multicollinearity Test}

The value of $\mathrm{R}^{2}$ of the two equations in Table 3 is compared with the same dependent variable (Open Unemployment Rate), so $\mathrm{R}^{2}$ is produced as it shown in table 3 . Klein's rule of thumb says that multicollinearity occurs if $\mathrm{R}^{2}$ obtained from auxiliary regression is higher than the overall $\mathrm{R}^{2}$ obtained from registering all X's variables to $Y$ (Ghozali and Ratmono, 2013: 84). The results in Table 3 show that the $R^{2}$ value of equation 1 is greater than the $R^{2}$ value of equation 2 . Therefore, it can be concluded that there is no multicollinearity in equation 1 , so that it is feasible to be tested in the next stage, namely testing the classical assumptions of autocorrelation.

Table 3 Multicollinearity Test

\begin{tabular}{|c|c|c|}
\hline No & Equation & Values of $\mathrm{R}^{2}$ \\
\hline 1 & $\begin{array}{l}\text { TPT }=f(\text { UMK, PDRB, TPAK, } \\
\text { RLS })\end{array}$ & 0,223 \\
\hline 2 & TPT $=\mathrm{f}(\mathrm{UMK}, \mathrm{PDRB}, \mathrm{TPAK})$ & 0,213 \\
\hline 3 & TPT = f(UMK,PDRB,RLS) & 0,214 \\
\hline 4 & TPT $=\mathrm{f}(\mathrm{UMK}, \mathrm{TPAK}, \mathrm{RLS})$ & 0,205 \\
\hline 5 & TPT $=f(P D R B, T P A K, R L S)$ & 0,198 \\
\hline
\end{tabular}

Source: research results, 2018

\section{Autocorrelation Test}

Based on the results of the autocorrelation test in table 4 , by looking at the Obs * Probability R-squared value of 0.283 is greater than alpha value of 5 percent $(0.05)$. The LM test results indicate the absence of autocorrelation in the regression model of this study. Thus it can be tested to the next stage, namely the classic assumption test of heteroscedasticity.

\section{Table 4}

\section{Autocorrelation Test}

\begin{tabular}{llll}
\hline Breusch-Godfrey Serial Correlation LM Test: \\
\hline F-statistic & 1,197823 & Probability & 0,316752 \\
Obs*R- & 5,036466 & Probability & 0,283576 \\
squared & & \\
\hline
\end{tabular}

Source: research results, 2018

\section{Heteroscedasticity Test}

The output results in table 5 show the probability value of Obs $* \mathrm{R}$-squared is 0.107172 greater than the alpha value of 5 percent $(0.05)$. This indicates there is no problem of heteroscedasticity in the regression model, so that it is feasible to be tested to the next stage of statistical test and short-term and long-term analysis (error correction model).

\section{Table 5 Heteroscedasticity Test}

\begin{tabular}{llll}
\hline White Heteroskedasticity Test: & \\
\hline F-statistic & 2.430678 & Probability & 0.102562 \\
$\begin{array}{l}\text { Obs*R- } \\
\text { squared }\end{array}$ & 21.61828 & Probability & 0.107172 \\
\hline
\end{tabular}

Source: research results, 2018

\section{Error Correction Model of Short-Term Analysis}

The ECM model is able to explain longterm and short-term dynamic behavior. The short-term regression coefficients of ECM regression are indicated by the magnitude of coefficients on the short-term variables in table 6, while the long-term regression coefficients with simulations from ECM regression are obtained from Table 7.

\section{Regency City Minimum Wage (UMK)}

The calculation results show that the district/city minimum wage coefficient for open unemployment in the short term is in accordance with the hypothesis, has a negative and significant effect that is equal to - 0.00000161 with a probability of 0.0000 . It means if there is an increase in the district/city minimum wage of 0.00000161 Rupiah, there will be a decrease in open unemployment by 1 percent. This is in accordance with the Phillips curve theory which states that when wages are high, unemployment is low. Therefore, if wages increase, it certainly encourages unemployed people to immediately find a job so that they can reduce unemployment.

Based on the results of research by Mansur, et al. (2014), wages have a negative and significant effect on unemployment in the city of Manado, which means that if wages increase it will affect the declining of the unemployment rate. The results of research conducted by Valentine (2018), Kurniawan (2017), Nurjanah (2017), Putri (2017), Azwar (2016), Sa'adah and Ardyan (2016), 
Octasari (2016), Ritonga (2015), Putri and Subroto (2015), Putri (2015), Rohman, et al (2015), Mansur, et al (2014), Nurcholis (2014), Soekarnoto (2014), Wijayanti and Karmini (2014), Sopianti and Ayuningsasi (2013), Haidy , et al (2012), Sucitrawati and Arka (2012), and Sulistiawati (2012), found a negative relationship between the minimum wage to the unemployment rate in accordance with the results in this study.

This means that the lower the wage level, the more open unemployment in all regencies/cities in Bali which tends to increase. Based on that, it can be interpreted that number of unemployment in the districts/ cities in Bali is influenced by the raise of regional minimum wages where minimum wages and unemployment have a negative relationship. With the increase in the level of wages, the urge to get a job or find work by the unemployed people will be more so that it will be able to reduce the level of unemployment.

The significance of district/city minimum wage in Bali for open unemployment is more to the large number of workers who do not work because they choose jobs with high wages or prefer to work abroad as Indonesian Workers (TKI) with relatively higher wages. Therefore, one of the ways to raise wages are by increasing programs of training for people in regencies/city throughout Bali as a form of improving human resources, so that the companies can provide jobs for them since companies definitely require professional staffs to run and develop their businesses. A company can be developed by increasing its human resources in order to raise income. The increased income of a company would raise the wages which in turn reduce the unemployment in districts/city throughout Bali.

This is in accordance with the theory stating that the most dominant and large factors which affect the high or low of wages are certification of competence and level of productivity of workers/laborers. That is, the more competency certification a worker/laborer has coupled with the higher productivity produced and the better results of the work done, it will automatically affect the greater salary or wage or at least takehome pay received (Kasim, 2014).

\section{Economic Growth (GRDP)}

The calculation results show the coefficient of economic growth for open unemployment in the short term is not in accordance with the hypothesis, and it is not significant. This result is different compared to the Okun's Law Theory. According to Mankiw (2006), Okun's Law states that there is a negative influence between unemployment and gross domestic product (GDP). Okun's law is a negative relationship between unemployment and real GDP, where every two percent increase in GDP will reduce one percent of unemployment (Samuelson and Nordhaus, 2004: 366). Based on this theory, the theory of Okun Law does not apply in regencies/cities throughout Bali.

This is likely to occur in districts/cities throughout Bali because the production process in Bali still tends to be capital intensive, namely the use of larger capital and more modern technology than employing human resources or intensive labor. Capital intensive occurs because the skills or level of education of labor force is still low, so companies prefer to increase capital intensive and use the latest technology to achieve production efficiency and maximize business profits.

Putri and Subroto (2015) concluded that variable of economic growth had no significant effect on the level of open unemployment in East Java. Kurniawan (2017), Rahmah and Murgianto (2016), Anggoro (2015), Fatimah and Syahnur (2015), Purnomo and Sukamdi (2014), Wijayanti and Karmini (2014), Astrini and Purbadharmaja (2013), Hajji and Nugroho (2013), also found that economic growth had no effect on the unemployment rate.

This is because not everyone has the opportunity to get a job. The variable of economic growth has a positive coefficient on the unemployment rate in Bali Province, which means that if the rate of economic growth increases, unemployment will also be high. The results of this study are in line with the research conducted by Sopianti and Ayuningsasi (2013) which obtained results that economic growth did not affect the number of unemployed people in Bali in 2004 to 2010. According to Kuznet (Boediono, 1999) economic growth is an increase in the capacity of the country concerned to provide a variety of economic goods to its population, meaning that the amount of domestic production is a measure of economic growth while a lot of labor is replaced by the use of technology.

Changes in the unemployment rate 
should be related to economic growth because it is a result of an increase in production capacity which closely associated with the increased use of labor. The results of the analysis are also in line with the results of research conducted by Trimurti and Komalasari (2014), which stated that economic growth has no significant effect on unemployment rates in seven provinces in Indonesia. Further, according to Trimurti and Komalasari (2014), achieving macroeconomic stability is not enough to create much-needed employment to reduce unemployment.

Rahmah and Murgianto (2016) report that GRDP has a negative relationship with the level of open unemployment in the city of Surabaya. This explains that in every increase of GRDP, the level of open unemployment in the city of Surabaya will decline, which means that GRDP does not significantly affect the unemployment rate in the city of Surabaya. This phenomenon occurs because economic growth is followed by increasing labor-oriented production capacity.

\section{Labor Force Participation Rate}

The calculation results show the coefficient of Labor Force Participation Rate (LFP) for open unemployment in the short term is in accordance with the hypothesis; it has a negative and significant effect which is equal to 0.041899 , which means there will be an increase in LFP of $0.041899 \%$ if open unemployment decrease of $1 \%$.

In accordance with previous empirical findings conducted by Utami, (2016), Azwar (2016), Fatimah dan Syahnur (2015), explains if the labor force participation rate has a negative and significant effect on the unemployment rate. 1 percent increase in male participation rate will reduce the unemployment rate by 0.12 percent and 1 percent increase in female labor force participation rate will reduce the unemployment rate by 0.13 percent. The effect of male labor force participation is slightly smaller in reducing the unemployment rate compared to female labor because male unemployment is greater than female unemployment due to the more male workforce available.

\section{Education (RLS)}

The calculation results show that the RLS coefficient of open unemployment in the short term has a positive but not significant effect. It means education is not a determining indicator of open unemployment in districts/ city throughout Bali. Kamaludin (1999: 59) says that the higher a person's education, the higher the ability and opportunity to work, thereby reducing the number of unemployed. Simanjuntak (1998: 70) explains if an increase in one's education will increase one's productivity so as to increase output; and an increase in output will have an effect on increasing labor demand to reduce the number of unemployed. Hence, the results of this study are not in accordance with the theory put forward by Kamaludin and Simanjuntak.

This is inversely proportional to the empirical findings made by Pratiwi and Zain (2014) who suggest that the role of education affects unemployment so it needs to increase quality and quantity. The research of Lathifah and Wibowo (2016) found that basic and high education factors influence open unemployment in East Java. Pratiwi and Zain (2014) point out the factors that influence open unemployment in North Sulawesi, one of which is the latest education.

The results of this research in regencies/ city throughout Bali showed different things. The growth in the average length of schooling in regencies and city in Bali Province has increased, but it is likely to also increase number of unemployed people. This condition occurs in Bali where in general the growth of the average length of schooling has increased but it is not too influential since the increase is still relatively low.

If the average number of achievements in the increase of average length of school is still taken, it still tends to be 7.7 years or equivalent to the first grade of junior high school. The average achievement of number of school years which only equal to the first grade of junior high school or 7.7 years of schooling will definitely in inadequate to enter the workforce that requires workers with expertise and average length of schooling of at least 12 years or more, and it resulted in the increase number of unemployed.

\section{Long-Term Analysis}

The interpretation of the results of longterm adjustment of explanatory variables using the ECM linear regression model is shown in Table 7. 


\section{Regency/City Minimum Wage (UMK)}

The demand for labor in Bali Province is not much influenced by annual wage increases, so that in the long run wages have a positive influence on open unemployment of 1.000004963 ; indicating that if there is an increase in the minimum wage of districts cities in Indonesia amounting to 1.000004963 rupiahs, there will be an increase in open unemployment by $1 \%$. In the long run, if the determination of the districts/cities minimum wage is high (raised), it can be seen from the company side that it will add it to the expenses of the company, so the company will take policies to optimize (reduce) number of workers which in turn increase number of unemployed. A wage increases of 1.000004963 Rupiah, when viewed from the side of a job seeker, will cause an increase in the unemployment rate because it has not reflected a salary increase so that it would not enough for them.

The increase in District/City Minimum Wages further encourages workers to find jobs, while for the business, the increase of Minimum Wages is not addressed by company management to reduce the number of workers but yet it is used as an important strategy in significantly improving employee performance, the sustainability of work unit, the realization of vision and mission and the achievement of work goals through high productivity which will ultimately reduce the existing unemployment rate. If a company is very burdened by the amount of Regency/ City Minimum Wage that has been determined and has not been able to adjust due to the increased production costs, then the company can submit a suspension of payment of the stipulated Regency/City Minimum Wage by showing evidence financial difficulties. Likewise, the company that cannot address the increase in the Regency/City Minimum Wage, which has an impact on increasing production costs, implementing a Termination of Employment (Layoffs) policy because Law No. 13 of 2003 concerning Manpower binds it.

The empirical findings conducted by Prawira (2018), Nurjanah (2017), Putro and Seriawan (2013), Hajji and Nugroho (2013), found results of the study that wage levels have a positive and significant effect on the unemployment rate. Different research results carried out by Hartanto and Masjkuri (2017), Sisnita (2017), Rahmah and Murgianto Prasanti, et al (2015) stated that the wage rate has a negative effect but it is not significant to the unemployment rate.

\section{Economic Growth (GRDP)}

The results of long-term calculations of 0.999999985 indicate that economic growth has a positive influence on open unemployment, i.e. there will be an increase in economic growth of $0.999999985 \%$ if there is an increase in unemployment of $1 \%$. Results of the study are the same as the results of research conducted by Hartanto and Masjkuri (2017), Dongoran, et al (2016), Siregar (2016), Ritonga (2015), Rohman, et al (2015), Nurcholis (2014), Subing (2013), who stated that economic growth has a positive effect on the unemployment rate.

Results of the study contradict with the results of research conducted by Latifah, et al (2017), Siregar (2017), Adawiyah and Seftarita (2016), Azwar (2016), Laksamana (2016), Octasari (2016), Parwata, et al (2016 ), Senet and Yuliarmi (2014), Oniore, et al (2015), Prasanti, et al (2015), Suwandika and Yasa (2015), Kusuma and Pitoyo (2014), Murniasih, et al (2014), Muslim (2014), Qomariyah (2014), Syahril (2014), Putro and Setiawan (2013), Rahmadin, et al (2013), Sanisah (2010), who stated that economic growth has a negative effect on the number of unemployment.

Economic growth increases and decreases will affect the fluctuations in number of unemployment which will have an impact on poverty. This is in accordance with the results of Jajang's research (2013) which shows that when the GRDP as the contribution of industrial labor, trade, and services increases, the number of poor people decreases. Whereas, if the population, contribution of labor in the agricultural sector,

Table 7

Long-Term Analysis

\begin{tabular}{|l|l|l|l|l|}
\hline Description & UMK/DMW & PDRB/GRDP & TPAK/LFP & RLS \\
\hline Results & $-1,000004963$ & 0,999999985 & 0,8708316 & 0,811348 \\
\hline
\end{tabular}

Source : research results, 2018 
and number of junior high school graduates increase, then number of poor people will also increase.

\section{Labor Force Participation Rate}

The results of long-term calculations of 0.8708316 indicate that the Labor Force Participation Rate (LFPR) has a positive effect on open unemployment; that there will be an increase in LFPR of $0.8708316 \%$ if there is an increase in open unemployment of $1 \%$. This indicates an increase in LFPR by choosing jobs hoping to receive high wages or prefer to work abroad as Indonesian Workers (TKI) with relatively higher wages so that open unemployment in regencies/city in Bali increases.

Empirical findings conducted by Relawan (2014) on the institutional role and contribution of micro-small enterprises (MSEs) to the economy in terms of employment, GRDP and the rate of economic growth (LPE) that employment accounted for $80 \%$, GDP contributed $42,78 \%$ and LPE contributed $2.95 \%$. This fact requires the government to be more proactive in empowering MSEs so that there is an increase in employment to overcome open unemployment.

\section{Education (RLS)}

The results of a long-term calculation of 0.811348 indicate that education has a positive effect on open unemployment, i.e. if there is an increase in education of 0.811348 years there will be an increase in open unemployment by $1 \%$. This condition is in line with the research conducted by Edi (2009), Suaidah and Cahyono (2013) which concluded that education has a positive and significant relationship because someone who has a high average length of school will tend to be more selective in choosing works/jobs in accordance with their fields and expertise.

\section{Adjustment Rate}

The rate of adjustment towards a long-term balance of -0.324375 is obtained from the amount of residual value of open unemployment rate $(-1)$. This adjustment means that in the long run there is an imbalance, within 3.08 months (100\%: $32.43 \%$ ) open unemployment balances by $32.43 \%$ on district/city minimum wages, economic growth, labor force participation rates, and the average length of schooling.

\section{Short-term Elasticity}

The elasticity of explanatory variables in the short term: the short-term elasticity of district/city minimum wage (UMK) on open unemployment (TPT) is indicated by the coefficient value of - 0.00000161 , while the economic growth elasticity (GDP) is 0.00000000471 , level elasticity labor force participation (TPAK) of 0.041899 , the elasticity of the average length of schooling (RLS) is equal to 0.06119 . The result indicates that the elasticity of the average length of schooling has the greatest effect on open unemployment.

\section{Long-term Elasticity}

Long-term elasticity: the district/ city minimum wage elasticity of open unemployment is -0.00000161 , gross regional domestic product elasticity of 0.00000000471 , the elasticity of labor force participation rate is -0.041899 , and the average school elasticity is 0.061194 . The result of this elasticity indicates that the average length of schooling has the greatest effect compared to other variables because the elasticity value is the greatest. The results of answers to the above analysis are supported by testing as follows :

The ECM estimation result shows that ECT is significant with $\alpha=5 \%$. This means the model specifications can be validated and give an indication of the short-term and long-term relationship of the observed variables.

\section{Conclusion}

Based on the above tests results, it can be concluded that in the short term variables which affect open unemployment are district/city minimum wages and labor force participation rates. In the long run the variables of district/city minimum wage, economic growth, labor force and education participation rates have a positive effect on open unemployment. The average elasticity of school years has the greatest influence compared to other variables. The rate of adjustment towards a long-term balance of 0.324375 means that there is an imbalance; in 3.08 months (100\%: $32.43 \%$ ) open unemployment balances by $32.43 \%$ on the district/city minimum wage, economic growth, labor force participation rate, and average length of schooling.

The minimum wage for workers which 
increases every year must be maintained by the government so that the employment rate continues to increase, thereby reducing number of open unemployment. Economic growth is followed by the increasing labororiented production capacity. Government should increase program training for people in Regency/city of Bali Province as an effort to improve human resources so that a company can provide an opportunity for the community to run and develop business enterprises with the need for professionals. The government should improve educational program, for example, School Operational Assistance (BOS), Indonesian Smart Card (KIP) to obtain an increase in average length of school in each district/city in accordance with the international provisions of 15 years.

\section{References}

Adawiyah, R and Seftarita, C. (2016). Analisis Pengaruh Inflasi and Pertumbuhan Ekonomi Terhadap Tingkat Pengangguran Terbuka Di Perbatasan Timur Indonesia. Jurnal I/miah Mahasiswa (JIM) Ekonomi Pembangunan Fakultas Ekonomi and Bisnis Unsyiah, 1(2).

Adipuryanti, Ni luh Putu Yuni, and I Ketut Sudibia. (2015). Analisis Pengaruh Jumlah Penduduk Yang Bekerja And Investasi Terhadap Ketimpangan Distribusi Pendapatan Melalui Pertumbuhan Ekonomi Kabupaten/Kota Di Provinsi Bali. PIRAMIDA Jurnal Kependudukan and Pengembangan Sumber Daya Manusia, 11 (1), 20-28.

Anderson, C., L. (2012). Opening Doors: Preventing Youth Homelessness Through Housing and Education Collaboration. Seattle Journal for Social Justice, 11(2).

Anggoro, M., H. (2015). Pengaruh Pertumbuhan Ekonomi And Pertumbuhan Angkatan Kerja Terhadap Tingkat Pengangguran Di Kota Surabaya. Jurnal Pendidikan Ekonomi, 3 (3), 1-13.

Astrini, Ni Made Myanti and Purbadharmaja, Ida Bagus Putu. (2013). Pengaruh PDRB, Pendidikan and Pengangguran Terhadap Kemiskinan Di Provinsi Bali. e-Jurnal Ekonomi Pembangunan Fakultas Ekonomi and Bisnis Universitas Udayana, 2(8), 384-392.

Azwar. (2016). Pertumbuhan Inklusif Di Provinsi Sulawesi Selatan And FaktorFaktor Yang Memengaruhinya. Jurnal Baand Pendidikan And Pelatihan Keuangan Kementerian Keuangan Republik Indonesia. 9(2).
Boediono. (1999). Teori Pertumbuhan Ekonomi. Yogyakarta: BPFE

Dongoran, Faisal R., Nisa Khairul., Sihombing Marni and Purba Lusita Devi. (2016). Analisis Jumlah Pengangguran And Ketenagakerjaan Terhadap Keberadaan Usaha Mikro Kecil And Menengah Di Kota Meand. Jurnal EduTech. 2(2), 59-72.

Edi, S. (2009). Manajemen Sumber Daya Manusia. Edisi Pertama. Jakarta: Kencana Prenada Media Group.

Fajrii, Arman and Yohanes. (2016). Dampak Otonomi Fiskal, Pertumbuhan Ekonomi, and Keterbukaan Daerah terhadap Ketimpangan Wilayah di Sumatera. Jurnal Ekonomi Kuantitatif Terapan, 9 (2).

Fatimah, Masbar Raja and Syahnur Sofyan. (2015). Analisis Faktor-Faktor Yang Mempengaruhi Tingkat Pengangguran Di Aceh. Jurnal Ilmu Ekonomi Pascasarjana Universitas Syiah Kuala, 3 (1).

Ghozali, I and Ratmono Dwi, R. (2013). Analisis Multivariat And Ekonometrika Teori, Konsep And Aplikasi Dengan Eviews 8. Fakultas Ekonomika and Bisnis Universitas Diponegoro Semarang.

Haidy N, A. Pasaya and Ratna Indrayanti. (2012). Pengangguran, Lama Mencari Kerja and Reservation Wage Tenaga Kerja Terdidik. Jurnal Ekonomi and Pembangunan Indonesia, 12(2).

Hajji Muhammad Shun and Nugroho SBM. (2013). Analisis PDRB, Inflasi, Upah Minimum Provinsi, And Angka Melek Huruf Terhadap Tingkat Pengangguran Terbuka Di Provinsi Jawa Tengah Tahun 1990-2011. e-Jurnal Diponegoro Journal of Economics, 2(3).

Hartanto, Trianggono Budi and Masjkuri, Siti Umajah. (2017). Analisis Pengaruh Jumlah Penduduk, Pendidikan, Upah Minimum and Produk Domestik Regional Bruto (PDRB) Terhadap Jumlah Pengangguran Di Kabupaten And Kota Provinsi Jawa Timur Tahun 2010-2014. Jurnal IImu Ekonomi, 2(1).

Insukindro. (1992). Pembentukan Model Dalam Penelitian Ekonomi. Jurnal Ekonomi and Bisnis. 1(7).

Jajang; Saefuddin, A; Mangku, I.W; and Siregar, H. (2013). Analisis Kemiskinan Menggunakan Model Panel Spasial Statik. Mimbar Jurnal. 29(2), 195-203. https:// ejournal.unisba.ac.id/index.php/mimbar/ article/view/396/307

Kamaluddin, R. (1999). Pengantar Ekonomi Pembangunan. Jakarta: Lembaga Penerbit Fakultas Ekonomi Universitas Indonesia.

Kasim Umar. (2013). Faktor-Faktor Yang 
Dapat Menentukan Besar Kecilnya Upah.www.hukumonline.com/klinik/ detail/1t51b57c1733caf/faktor-faktoryang-dapat-menentukanbesar-kecilnyaupah

Kurniawan, A. (2017). Determinant Factors of The Performance Indicator of Local Government (Study towards Performance Indicator of Economic Growth and Open Unemployment Rate in Sidoarjo Regency). Wacana. 20(1).

Kusuma, Efri Dian and Pitoyo, Agus Joko. (2014). Dinamika Penganggur Terbuka Di Provinsi Riau Tahun 2008-2013. https://media.neliti.com/media/ publications/228358-none-07f7cdac.pdf.

Laksamana, R. (2016). Pengaruh PDRB Terhadap Pengangguran Di Kabupaten/ Kota Kalimantan Barat. Jurnal Audit and Akuntansi Fakultas Ekonomi and Bisnis Universitas Tanjungpura, 5(2).

Latifah Neny, Debby C.H. Rotinsulu, Richard L.H Tumilar. (2017). Pengaruh Pertumbuhan Ekonomi and Indeks Pembangunan Manusia Terhadap Tingkat Pengangguran Terbuka and Dampaknya Pada Jumlah Penduduk Miskin Di Kota Manado. Jurnal Berkala Imiah Efisiensi, 17(2).

Lathifah Arinda Nur and Wibowo Wahyu. (2016). Pemodelan Angka Pengangguran Pernah Bekerja and Belum Bekerja di Jawa Timur Menggunakan Metode Regresi Multivariat. Jurnal Sains and Seni ITS, 5(2).

Mankiw, G. (2006). Pengantar Ekonomi Makro. Edisi Ketiga. Jakarta: Salemba Empat

Mansur, Nirmala, Daisy Engka and Steeva Tumangkeng. (2014). Analisis Upah Terhadap Pengangguran Di Kota Manado Tahun 2003-2012. Jurnal Berkala IImiah Efisiensi, 14(2).

Murniasih, Ni Kadek, Dunia Ketut and Meitriana Made Ary. (2014). Pengaruh Nilai PDRB, Tingkat Upah and Tingkat Inflasi Terhadap Pengangguran Terbuka Provinsi Bali Tahun 2003-2012. Jurnal Ekonomi and Bisnis, 4(1).

Muslim Mohammad Rifqi. (2014). Pengangguran Terbuka and Determinannya. Jurnal Ekonomi and Studi Pembangunan, 15(2).

Nurcholis, M. (2014). Analisis Pengaruh Pertumbuhan Ekonomi, Upah Minimum and Indeks Pembangunan Manusia Terhadap Tingkat Pengangguran Di Provinsi Jawa Timur. Jurnal Ekonomi Pembangunan, 12(1).

Nurjanah Miftah Intan. (2017). Analisis Determinan Tingkat Pengangguran
Kabupaten/Kota Di Jawa Tengah Tahun 2010-2015. e-jurnal Prodi Ekonomi Pembangunan S1 Fakultas Ekonomi and Bisnis Universitas Muhammadiyah Surakarta.

Octasari, T. (2016). Pengaruh Pertumbuhan Ekonomi, Upah Minimum, And Tingkat Pengangguran Terhadap Jumlah Penduduk Miskin Di Indonesia Tahun 2009-2013. Jurnal Pendidikan and Ekonomi, 5(6).

Oniore, Johathan; Bernard, Anthony; Gyang, Emily. (2015). "Macroeconomic Determinants of Unemployment in Nigeria". International Journal of Economics, Commerce and Management, C.3, S.10, s. 215-230.

Parwata, I Made, Suwendra I Wayan and Yudiaatmaja Fridayana. (2016). Pengaruh Produk Domestik Regional Bruto (PDRB) and Tingkat Pengangguran Terbuka Terhadap Tingkat Kemiskinan. e-journal Bisma Universitas Pendidikan Ganesha Jurusan Manajemen, 4.

Prasanti Tyas Ayu, Wuryandari Triastuti and Rusgiyono Agus. (2015). Aplikasi Regresi Data Panel Untuk Permodelan Tingkat Pengangguran Terbuka Kabupaten/Kota Di Provinsi Jawa Tengah. e-jurnal Gaussian Jurnal Statistika Universitas Diponegoro, $4(3)$.

Pratiwi F. E. and Zain I. (2014). Klasifikasi Pengangguran Terbuka Menggunakan CART (Classification and Regression Tree) di Provinsi Sulawesi Utara. Jurnal Sains and Seni POMITS. Volume 3 Nomor 1 pp. D-54-D-59.

Prawira Syurifto. (2018). Pengaruh Pertumbuhan Ekonomi, Upah Minimum Provinsi and Tingkat Pendidikan Terhadap Pengangguran Terbuka Di Indonesia. Jurnal Mahasiswa Pendidikan Ekonomi, $1(2)$.

Putri, Dwi Aprilia and Subroto, Waspodo Tjipto. (2015). Analisis Beberapa Faktor Yang Mempengaruhi Tingkat Pengangguran Terbuka Di Jawa Timur Tahun 2003-2014. e-Jurnal Fakultas Ekonomi Universitas Negeri Surabaya.

Putri Titis Sudhani. (2017). Analisis Pengaruh Inflasi, Investasi, Upah Minimum and Pertumbuhan Ekonomi Terhadap Pengangguran Di Ekskariseandan Surakarta Periode Tahun 2010-2014. Skripsi Program Studi Strata 1 Jurusan Ilmu Ekonomi Studi Pembangunan Fakultas Ekonomi and Bisnis Universitas Muhamadiyah Surakarta.

Putri Dwi Aprilia and Subroto Waspodo Tjipto. (2015). Analisis Beberapa Faktor Yang 
Mempengaruhi Tingkat Pengangguran Terbuka Di Jawa Timur Tahun 2003-2014. e-Jurnal Fakultas Ekonomi Universitas Negeri Surabaya.

Putro Akbar Sis and Setiawan Achmad Hendra. (2013). Analisis Pengaruh Produk Domestik Regional Bruto, Tingkat Upah Minimum Kota, Tingkat Inflasi and Beban/Tanggungan Penduduk Terhadap Pengangguran Terbuka Di Kota Magelang Periode Tahun 1990-2010. e-jurnal Diponegoro Fakultas Ekonomika and Bisnis Universitas Diponegoro, 2(3).

Purnomo Adi and Sukamdi. (2014). Karakteristik Penganggur Terbuka, Setengah Penganggur and Pertumbuhan Ekonomi di Propinsi Jawa Timur (Analisa Data Sakernas Agustus Tahun 2010). Jurnal Bumi Indonesia, 1(2). http://lib. geo.ugm.ac.id/ojs/index.php/jbi/article/ view/16

Qomariyah, I. (2014). Pengaruh Tingkat Inflasi and Pertumbuhan Ekonomi Terhadap Tingkat Pengangguran Di Jawa Timur. Jurnal Pendidikan Ekonomi (JUPE), 1(3) Universitas Negeri Surabaya.

Rahmah, Dinni Elinda and Murgianto. (2016). Pengaruh PDRB and Upah Minimum Terhadap Tingkat Pengangguran Di Kota Surabaya Tahun 2010-2014. Jurnal Ekonomi and Bisnis, 1(2).

Rahmadin, Hamzah Abu bakar and Nasir, M. (2013). Pengaruh Investasi and Pertumbuhan Ekonomi Terhadap Tingkat Pengangguran Di Provinsi Aceh. Jurnal IImu Ekonomi Pascasarjana Universitas Syiah Kuala, 1(4).

Relawan, Ida Nurnida. (2014). Peran Kelembagaan Usaha Mikro and Kecil (UMK) terhadap Laju Pertumbuhan Ekonomi (LPE) Jawa Barat. Mimbar Jurnal, 30(2), 159-170. https://ejournal.unisba. ac.id/index.php/mimbar/article/view/598

Ritonga, A. (2015). Analisis Faktor-Faktor Yang Mempengaruhi Tingkat Pengangguran Di Provinsi Sumatera Utara. Karismatika, 1(3).

Rohman Mualif Ainur, Balafif Mamak Moh and Wahyuni Susi Tri. (2015). Pengaruh PDRB, Inflasi and UMR Terhadap Pengangguran Terbuka Di Jawa Timur Tahun 1994-2013. fe.ubhara.ac.id/ojs/index.php/global/ article/download/242/227

Sa'adah, Nuvi Wikhdatus and Ardyan, Putu Sardha. (2016). Analisis Pengaruh Upah Minimum Pekerja and Jumlah Penduduk Miskin Terhadap Tingkat Pengangguran Di Kota Surabaya. Jurnal Ekonomi and Bisnis, 1(2).
Samuelson, Paul A and Nordhaus, William D. (2004). Ilmu Makro Ekonomi. Jakarta:P.T.Media Global Edukasi

Sanisah, S. (2010). Pendidikan Tinggi and Pengangguran Terbuka. Lentera Pendidikan, 13(2).

Senet, Putu Dyah Rahadi and Yuliarmi, Ni Nyoman. (2014). Faktor-Faktor Yang Mempengaruhi Jumlah Pengangguran Di Provinsi Bali. e-jurnal Ekonomi Pembangunan Universitas Udayana, 3(6), 237-246.

Simanjuntak, Payaman J. (1998). Pengantar Ekonomi Sumber Daya Manusia. Jakarta: LPFEUI.

Siregar, S. (2017). Pengaruh PDRB Riil and Inflasi Terhadap Tingkat Kemiskinan Kota Meand Dengan Variabel Intervening Pengangguran. Jurnal Ilmiah Methonomi, $3(2)$.

Siregar, S. (2016). Pengaruh PDRB Riil and Inflasi Terhadap Pengangguran Kota Meand. Jurnal IImiah Methonomi, 2(1).

Sisnita, A. (2017). Analisis Faktor-Faktor Yang Mempengaruhi Tingkat Pengangguran Terbuka Di Provinsi Lampung Perideo 2009-2015. Skripsi Program Studi Strata 1 Jurusan Ilmu Ekonomi Studi Pembangunan Fakultas Ekonomi and Bisnis Universitas Muhamadiyah Surakarta.

Soekarnoto, Tengkoe Sarimuda RB. (2014). Pengaruh PDRB, UMK, Inflasi and Investasi Terhadap Pengangguran Terbuka di Kab/ Kota Provinsi Jawa Timur Tahun 20072011. Jurnal Ekonomi and Bisnis, 14(2).

Sopianti, Ni Komang and Ayuningsari, A.A Ketut. (2013). Pengaruh Pertumbuhan Ekonomi, Tingkat Inflasi and Upah Minimum terhadap Jumlah Pengangguran di Bali. e-jurnal Ekonomi Pembangunan Universitas Udayana, 2(4), 216-225, (http://download.portalgaruda.org/ article. php?article=823 19\&val=981.

Suartha, Nyoman and I Gst Wayan Murjana Yasa. (2017). Pengaruh Pertumbuhan Ekonomi, Migrasi Masuk Terhadap Pertumbuhan Penduduk and Alih Fungsi Bangunan Penduduk Asli Kota Denpasar. Jurnal Ekonomi Kuantitatif Terapan (JEKT), 10 (2), 95-107.

Sucitrawati, Ni Putu and Arka, Sudarsana. (2012). Pengaruh Inflasi, Investasi and Tingkat Upah terhadap Tingkat Pengangguran di Bali. e-jurnal Jurusan Ekonomi Pembangunan Fakultas Ekonomi and Bisnis Universitas Udayana, 5 (1), 69-95.

Sulistiawati, R. (2012). Pengaruh Upah Minimum terhadap Penyerapan Tenaga 
Kerja and Kesejahteraan Masyarakat di Provinsi di Indonesia. Jurnal EKSOS, 8(3).

Suaidah, Imarotus and Cahyono, Hendry. (2013). Pengaruh Tingkat Pendidikan Terhadap Tingkat Pengangguran Di Kabupaten Jombang. Jurnal Pendidikan Ekonomi (JUPE), 1(3), Universitas Negeri Surabaya

Suwandika, Putu Eka and Yasa, I Nyoman Mahaendra. (2015). Pengaruh Pendapatan Asli Daerah and Investasi Terhadap Pertumbuhan Ekonomi and Tingkat Pengangguran Di Provinsi Bali. e-jurnal Ekonomi Pembangunan Universitas Udayana, 4(7).

Syahril. (2014). Analisis Pengaruh Pertumbuhan Ekonomi and Kesempatan Kerja Terhadap Pengangguran Di Kabupaten Aceh Barat. Jurnal Ekonomi and Kebijakan Publik Indonesia, 1(2).

Subing, A. (2013). Pengaruh Pengeluaran Aggregat Terhadap Pertumbuhan PDRB and Pengaruh Pertumbuhan Sektor Primer, Sekunder and Tersier, terhadap Pengangguran and Kemiskinan di Provinsi Lampung. Jurnal Ekonomi, 15(3).

Thomas,R.L., (1993), Modern Econometrics, International Edition, Addison-Wesley, UK Trimurti, C.P and Komalasari, Y. (2014).
Determinants of Unemployment : Empirical Evidences from 7 Province in Indonesia. Scientific Research Journal (SCIRJ), 2(8). Utami, Wahyu Tiani, Rohman Abdul and Prahutama, Alan. (2016). Pemodelan Regresi Berganda And Geographically Weighted Regression Pada Tingkat Pengangguran Terbuka Di Jawa Tengah. Media Statistika, 9(2).

Valentine, Shaila Riri. (2018). Pengaruh Inflasi, UMR, Jumlah Pariwisata and PDRB Terhadap Pengangguran Di DIY (Tahun 2000-2015). Skripsi Program Studi Ilmu Ekonomi Fakultas Ekonomi Universitas Islam Indonesia Yogyakarta

Wiguna, V., I. (2013). Analisis Pengaruh PDRB, Pendidikan And Pengangguran Terhadap Kemiskinan Di Provinsi Jawa Tengah Tahun 2005-2010. Jurnal IImu Ekonomi, Fakultas Ekonomi and Bisnis Universitas Brawijaya Malang.

Wijayanti, Ni Nyoman S.A and Karmini, Ni Luh. (2014). Pengaruh Tingkat Inflasi, Laju Pertumbuhan Ekonomi And Upah Minimum Terhadap Tingkat Pengangguran Terbuka Di Provinsi Bali. e-Jurnal Ekonomi Pembangunan Universitas Udayana, 3(10), 460-466. 